\title{
Efficiency of Islamic and Conventional Banks in Pakistan: A Non-parametric Approach
}

\author{
Muhammad Azeem Qureshi \\ School of Business \\ Oslo and Akershus University College of Applied Sciences \\ Oslo, Norway \\ E-mail: muhammad-azeem.qureshi@hioa.no \\ Madeeha Shaikh \\ Institute of Management Sciences \\ Bahauddin Zakariya University \\ Multan, Pakistan \\ E-mail: madeeha.shkh@gmail.com
}

Received: January 17, 2012

Accepted: February 7, 2012

Published: April 1, 2012

doi:10.5539/ijbm.v7n7p40

URL: http://dx.doi.org/10.5539/ijbm.v7n7p40

\begin{abstract}
The purpose of this paper is to analyze comparative efficiency of banking system in Pakistan comprising of Islamic banks (IB), conventional banks with Islamic banking division (IBD) and conventional banks (CB). For this purpose we use two methods: First, ratio analysis to analyze cost, revenue and profit efficiency; Second, data envelopment analysis (DEA), for comparative analysis of banks' technical, pure technical and scale efficiencies. We use efficiency scores of DEA to analyze the impact of size on the efficiency. Finally, we compare and contrast the efficiency estimates with the traditional measures of banks efficiency. We find that Islamic bank is more cost efficient and less revenue efficient. Considering their growth rate which is rudiment to scale efficiency (SE) we argue that Islamic banks should be encouraged to reach the efficient frontier in the banking industry by reducing their wastes. We further observe that hybrid banking may not be feasible form for banking industry in Pakistan. In view of the observed inverse relationship of size with scale efficiency we recommend reconsideration of the regulators' policy of increasing the capital base of the banks thus forcing them to increase their size.
\end{abstract}

Keywords: Banking efficiency, Ratio analysis, Data envelopment analysis, Pakistan

\section{Introduction}

Developing and transition economies, Pakistan alike, provide a unique opportunity to study the impact of liberalization and deregulation on the efficiency and performance of the banking sector. Pakistan is also in the process of building a strong banking platform where its central bank, State Bank of Pakistan (SBP), regulates the sector to gradually bring reforms which on one hand may open new windows of opportunity for the industry players, and on the other hand may create distortions resulting in inefficient resource allocation (Akmal \& Saleem, 2008). In such a case analysis of bank efficiency is important from the point of view of investors, creditors, the government and the bank's management (Al-Shammari \& Salimi, 1998).

There has been a fast expansion of banking institutions over the decades. Besides this there is also the proliferation of financial crises and inefficient banks. The recent financial crisis experienced by the conventional banking sector around the world has pushed the Islamic banking sector to further emphasize on transparency and avoidance of undue risk to insulate themselves from the crises (Akmal \& Saleem, 2008; Johnes, Izzeldin, \& Pappas, 2009). Islamic and conventional banks are in direct competition and efficiency has proved to be a tool for winning the competition. Having the same factors of production, the efficient usage of inputs determines the success (Danesh, 2007). 
Generally there are two ways to study banking efficiency; traditional financial ratios and non-parametric approaches like data envelopment analysis (DEA). For the purpose of this paper we use both: DEA to measure the technical, pure technical and scale efficiency scores for the banks, and ratio analysis to compare and contrast with the results of DEA. As such we consider the two methods as supplement and not the substitute for each other.

Apart from the introduction in this section rest of the paper is organized as follows: section 2 contextualizes the research problem by giving an overview of the banking sector of Pakistan, section 3 reviews the relevant literature on banks' efficiency, section 4 describes the data and discusses the methodology along with the approaches used to estimate efficiency scores, section 5 discusses the results, section 6 provides concluding remarks, and we give references at the end.

\section{Banking Sector of Pakistan}

Pakistan had been trying to implement comprehensive interest free banking at national level (Iimi, 2004). Currently about 45 countries, encompassing majority of the Muslim and a few non-Muslim countries, have some type of Islamic banking or financial institutions.

In Pakistan the practical measures for initiating interest free banking included the introduction of Zakat in June 1980 and Ushr in March 1983 and elimination of interest from the operations of specialized financial institutions during July 1979 to July1985 and from the commercial banks during January 1981 to July 1985 . Commercial banks transformed their nomenclature during January 1981 to June 1985 based on the 12 modes but since July 1985 all commercial banking in Pak Rupees was declared interest-free. But the procedure adopted by the banks was declared un-Islamic by the Federal Shariah Court of Pakistan in the year 1991 and the Shariah Appellate Bench of Supreme Court of Pakistan ordered to remove all the interest based practices by June 2001. However, foreign dealings were exempted from this order. Due to difficulties and risks of a comprehensive transformation, it was decided to promote Islamic banking in parallel with conventional system (S.B.P., 2007). Resultantly an Islamic bank started its operation in January, 2001 and since then an increasing number of private Islamic banks have been operating in the country along with conventional banks in public as well as private sector. Islamic banking remained resilient, despite some negative shocks witnessed by the banking sector in Pakistan. The growth in assets, deposits, financing, investment, and number of branches of Islamic banking is remarkable.

\section{Banking efficiency studies utilizing DEA}

In the past few years DEA has been frequently applied to the banking industry studies along with ratio analysis to check the consistency of results of both methods. A number of studies applied DEA and ratio analysis in a number of different contexts (Al-Shammari \& Salimi, 1998; Isik \& Hassan, 2002; Omar et al., 2006; Tortosa-Ausina, 2004; Yeh, 1996; Yudistira, 2003), we however, review a few studies here.

A study of Indian commercial banks suggests that average cost efficiency of Indian banks was quite low at $23 \%$. Correlating the efficiency scores with ROA and ROE, it observes that profit efficiency and accounting measures have a strong association. Moreover, correlation of the efficiency results with size of banks indicates that large size banks are more profit efficient than their small counterparts. Thus small banks in India may increase their size to be more profit efficient without any major cost disadvantage (Das \& Ghosh, 2009).

A study of 139 banks in Turkey uses DEA in order to determine the efficiency frontier to compare the relative efficiencies of these banks. This study finds technical inefficiency in Turkish banks higher than allocative inefficiency, which suggests that Turkish banks are good at selecting the cost efficient mix of inputs but are inefficient to utilize them resulting into waste of inputs. The correlation results between financial ratios and efficiency measures depict a strong association between them. Other findings are: the private banks are less technically efficient than public banks, also multinational and domestic banks have almost same efficiency scores (Isik \& Hassan, 2002).

Another application of DEA in combination with financial ratio analysis is on the Islamic and conventional banks in gulf region over the period 2004 to 2007. The financial ratio results depict that Islamic banks are less cost efficient but more revenue and profit efficient than conventional banks. The DEA results suggest that conventional banks are, on the average, more efficient than Islamic banks. Moreover, the study finds significant correlations between DEA and ratios results in cost only (Johnes, et al., 2009). Contrary to these results, Islamic banks are reported to be more efficient than their conventional counterparts from 2000-2005. Despite their large size conventional banks did not surpass Islamic banks in efficiency scores (Grigorian \& Manole, 2005).

\subsection{Window Analysis}

A study on six banks in Singapore uses window analysis approach of DEA, a novelty for small sample to measure their efficiency. The decomposition of overall technical efficiency into pure technical and scale efficiencies 
suggests that banks in Singapore are increasing their size with mergers and acquisitions resulting in their decreasing returns to scale despite large sizes and assets. Also there is a strong association between the efficiency scores and accounting measures of banks performance (Sufian, 2007). Using Charnes, Cooper and Rhodes (CCR) model for constant returns to scale (CRS) with window analysis approach, the analysis of 24 Islamic banking institutions in Iraq shows that the number of banks on efficient frontier increases over time from 9 to 16 from 1999 to 2001 (Al-Delaimi \& Al-Ani, 2006).

\subsection{DEA studies in Pakistan}

There are only a few efficiency studies using DEA of only conventional banks in Pakistan, as Islamic banking is still in its infancy stage. Using both input and output oriented models of DEA, the analysis of post liberalization efficiency and productivity of conventional banks in Pakistan indicates no improvement in productivity and efficiency (Rizvi, 2001). Another study suggests foreign banks to be more efficient in resource utilization and identifies allocative inefficiency as a major cause of cost inefficiency for domestic banks (Niazi, 2003). Generally, banking efficiency has improved since 2000 and the foreign banks are more efficient than local private and state owned banks. Banking sector in Pakistan has witnessed technological and total factor productivity growths during 1995 to 2005 (Akmal \& Saleem, 2008). A study of 37 Pakistani commercial banks for the years 2001-2004 suggests that they should increase their assets and interest earnings to improve efficiency; and cut down their non-interest expenses and liabilities to have a positive impact on efficiency. However, it argues that the government should not promote the merger activity of commercial banks rather the banks should focus to enhance their efficiency to increase their profits (Ahmed, 2008).

\section{Methodology and Data Description}

Traditionally financial ratios have been used to assess the financial performance of any firm including banks. However, the advancement in quantitative techniques resulted in a shift towards parametric and non-parametric frontier efficiency estimations. For the purpose of this paper we will use both the methods to identify whether the DEA efficiency scores are in conjunction with the ratio scores or both the methods lead to different insights. Table 1 shows the ratios used in previous studies for efficiency comparisons of banks.

\section{Insert Table 1 here}

As an alternate to regression analysis, DEA bases itself on linear programming technique to measure efficiency (Avkiran, 1999). DEA measures the efficiency of a bank relative to other similar banks with a restriction that all the banks lay on or below the efficient frontier. The frontiers constructed are non-statistical or non-parametric in the sense that they are constructed through the envelopment of the decision making units (DMUs) with the best practice DMUs forming the non-parametric frontier.

The CCR model (introduced in 1978) grounds itself on the assumption of constant returns to scale and optimal scale operations. While the BCC (introduced in 1984), an extension to CCR model, assumes variable returns to scale and adds a convexity condition to CCR model. Thus the efficiency estimated using BCC refers to the pure technical efficiency (PTE) while the efficiency score using CCR refers to the technical efficiency (TE) which may be decomposed as PTE and Scale Efficiency $(\mathrm{SE})$ : TE $=$ PTE $\times$ SE. To measure efficiency there are two possibilities; first, input oriented model aims to minimize inputs with at least the given output levels; and two, the output oriented model attempts to maximize outputs given the existing inputs (Cooper et al., 2007). Both orientations recognize the same DMU as efficient, however scores assigned to inefficient units are not the same in both orientations (Seelanatha, 2007). For the purpose of this study, we use the output oriented approach as it assumes that the firms can maximize their outputs by whatever resources they have. Considering the small sample size we will also employ window analysis to estimate the efficiency scores, which considers each DMU as a separate entity in each of the reporting years that allows greater degrees of freedom and provides meaningful insights (Cooper, et al., 2007). A DMU may have different efficiency score for the same year in different windows. This property allows checking for the consistency of the efficiency scores. Generally, the size of window should be less than the total number of years and for this paper, following (Sufian, 2007) we use a 3 year window for the DMUs.

We will employ commonly used intermediation approach which assumes that a bank brings together deposits and purchased funds through labor and capital to transform (intermediate) sources of funds into earning assets. The literature is a bit vague and contentious in defining input-output variables for banks, an important part of the DEA model, e.g. deposits had been taken as input and output both in various researches. Considering intermediation approach and following the prevalent view (Danesh, 2007) we use the following inputs-outputs. 
We have selected a bank from each type of banking structure i.e. Islamic bank (IB), pure conventional bank (CB) and conventional with Islamic banking division (IBD), as the studies selecting varying number of banks of each type can be misleading if there exist differences in banking operations of each type (Hassan, 2005). Islamic banking is a new phenomenon in Pakistan and we have sufficient data coverage of 6 years from 2003-2008 only for one bank, which makes it our period of analysis and this IB as part of our sample. Moreover, we select two domestic private banks; IBD represents the highest share in Islamic banking industry (S.B.P., 2008), and the CB having closest asset size to the other two selected banks to avoid the impact of bank's size on its efficiency. All the three selected banks have not gone under any merger/acquisition in Pakistan which may affect efficiency of banks (Sufian, 2007), which keeps the focus endogenous.

\section{Empirical Results and their Discussion}

\subsection{Ratio results}

Figures 1 and 2 depict the cost, revenue and profit efficiency of the three banks. Figure 1 shows that CB is the most cost efficient bank throughout 2003-2008, IB is generally cost inefficient which may be due to two reasons: first, they have to maintain Shariah boards to ensure Shariah compliance; and two, a probable higher legal cost because of relative complexity of Islamic products (Johnes et al., 2009). We observe an increasing trend in non-interest expenses for all the three banks due to increased overhead costs for year 2008 owing to branch expansion and increased competition as well as growth of non-performing loans which are generally inevitable consequence of expanding credit portfolios (S.B.P., 2008). It is interesting to note that cost to income ratio of IBD has generally remained highest indicating operating inefficiency of this hybrid banking as compared to its pure form competitors.

\section{Insert Figure 1 here}

Figure 2 demonstrates that IB is most revenue efficient. The probable explanation may be their risk-averse credit or better product and/or governance structure resulting into a less variant efficiency curves. The net interest margin shows that IB is more efficient in the usage of their earning assets and investments. The democratization process in the country and consequent macroeconomic stability has a generally positive effect on net interest margin of the three types as reflected by its increasing trend. However, the defaults in consumer and other small financing of CB resulted into decline in its net interest margin in 2004 and 2007. A simultaneous view of net interest margin and other income to assets ratio graphs indicates that all the three banks have gradually shifted their focus primarily to the banking operations resulting into an increasing trend in net interest margin and decreasing trend in other income to assets ratio.

\section{Insert Figure 2 here}

We observe, in Figure 3, a generally decreasing trend showing a sign of recovery later on in return on equity and return on assets of the three banks which is primarily due to four reasons: first, increased equity base of banks as the capital requirement for the banks is increased from PKR 500 million to PKR 1 billion in 2004 and continues to increase by PKR 1 billion each year (S.B.P., 2007); two, increased equity base also increased assets base which was initially idle cash resulting into a sharp decline but gradually the situation eased; third, higher provisions for non-performing loans to comply with gradually stringent regulatory framework of SBP; and fourth, lately banks were able to increase their spread between deposit and loan rate which explains the improvement in both return equity and returns on assets.

Insert Figure 3 here

\subsection{DEA Scores}

\subsubsection{Overall Technical Efficiency}

Table 3 presents the CCR scores measuring the overall technical efficiency for the three banks. As a consequence of banking reforms the banks witnessed growth in revenue and assets in 2003 which was the most efficient year for all three types with less than $15 \%$ waste of inputs. On the other hand, in 2007 and 2008 banking industry in Pakistan generally faced reduction in deposits and advances due to reduced economic activity and increased inflation in the country, and such these were most inefficient years for CB. However, CB is far better than the two counterparts throughout the study period. The IBD proved to be inefficient in 2006 due to huge non-performing loans in consumer financing sector (S.B.P., 2008). Interestingly we observe lesser volatility in the efficiency scores for IB throughout the study period which indicates better governance structure and product portfolio at IB that has shown resilience against economic shocks felt by the competition. We observe a huge $22.1 \%$ input waste for IBD which clearly suggests that hybrid form of the banking may not be feasible in Pakistan. The results; with mean overall score for CB is $98.1 \%$ with only $1.9 \%$ waste, IB with $89.5 \%$ with $10.5 \%$ waste and IBD with $77.9 \%$ with 
$22.1 \%$ waste; are quite consistent with the mean overall efficiency score of $88.2 \%$ for overall Pakistani banking industry (Akmal \& Saleem, 2008), indicating a good representative sample for this study.

Insert Table 3 here

\subsubsection{Pure technical efficiency}

Table 4 shows the BCC model scores, which depict PTE of a DMU which is the technical efficiency excluding the scale inefficiencies of the banks and envelops the data more closely thus allows for high efficiency scores (Niazi, 2003). We observe that score for CB is highest which shows that it lies on both the CCR and BCC frontiers and thus enveloping the other two. The IBD closely follows CB on PTE with a minor difference of $1 \%$. On BCC frontier IB is the least PT efficient with less than optimal utilization of its deposits and expenses to generate output. Another study finds PTE score for banking industry of Pakistan at 91.7 \% (Akmal \& Saleem, 2008) and our results are quite close to this and suggest a proper sample selection for this study as well as indicate that the banks need to better utilize the available resources.

\section{Insert Table 4 here}

\subsubsection{Scale Efficiency}

Table 5 depicts the SE score for the three bank types with CB having the highest score which shows a declining trend in 2007 and 2008 owing to non-performing loans (S.B.P., 2008). For IB we observe lesser variability in its $\mathrm{SE}$, a major contributor in its overall efficiency, indicating a better strategic and operational management. The BCC and SE scores of IBD suggest that it could not manage its resources well enough to generate the revenues and earning assets and as such scale inefficiency becomes a major contributor to its overall inefficiency. The mean efficiency scores for CB, IBD and IB are $98.0 \%, 78.6 \%$ and $94.5 \%$. Compared with the average SE of banking sector of Pakistan at 96\% (Akmal and Saleem 2008), under performance of IBD clearly suggests infeasibility of this banking type and calls for a strategic rethinking of a shift to pure form banking.

Insert Table 5 here

\subsection{Efficiency versus assets}

Empirical evidence on impact of bank size on its efficiency is mixed; some suggest that increase in bank size improves its efficiency (Das \& Ghosh, 2009; Drake, Hall, \& Simper, 2006; Yudistira, 2003), while others present evidence that banks could not maintain their efficiency consequent to mergers/acquisitions/network expansion (Bdour \& Al-khoury, 2008; Danesh, 2007; Sufian, 2007). Figure 4 show that OTE of all the three banks decreases with the increase in assets with the largest asset structure IBD is the most OTE inefficient. PTE shows positive relation to the increase in size of banks.

\section{Insert Figure 4 here}

On the other hand their SE deteriorated. Thus with more assets bank should try to focus on maintaining their scale of operations either constant or increasing. It is also noticeable that the PT efficiency for IB is less than its counterparts despite of asset increase due to the limited availability of low risk and Shariah compliant investment opportunities for IB. Another important aspect is that the three types of banks showed similar response to the increase in size. Hence, increase in size does not ensure increased efficiency; in order to achieve the efficient frontier banks should maintain their focus on SE.

\subsection{Consistency of DEA and Ratio results}

Even though ratio analysis and DEA are based on two completely different principles but still they may be used for the same purpose and many studies depict a strong consistency in the ratio results and DEA scores (Das \& Ghosh, 2009; Isik \& Hassan, 2002; Sufian, 2007; Yeh, 1996). Table 6 provides a comparison between five financial ratios and the DEA results. The bank rankings obtained from the DEA scores are significantly and positively correlated to only two profit ratios. There is no evidence of any significant positive relationship in other financial ratios and DEA overall efficiency scores. This contradicts with the notion that banks that are inefficient under the DEA approach could be actually more profitable than DEA efficient ones (Johnes, et al., 2009). The Spearman and Pearson's correlations between the two profit ratios and DEA efficiencies shows that the banks on the efficient frontier are also profitable under the financial analysis. However, the cost and revenue ratios are not correlated with the efficiency scores. The correlation evidence therefore suggests that financial ratio analysis and DEA should be considered as a complementary rather than competing (Danesh, 2007).

\section{Insert Table 6 here}




\section{Conclusion and policy recommendations}

The purpose of this paper is to provide an in-depth analysis of efficiency of IB, CB and IBD in Pakistan over the period 2003-2008 using financial ratio analysis and DEA. The CB has a long history and very strong and deep roots in Pakistan, while IB is in its infancy stage and the regulator's induced IBD is also a new experimentation. The financial ratio analysis suggests that IB is less cost efficient and more revenue efficient than the other two counter parts. Considering the market penetration of IBs, gaining a share of $4.4 \%$ of overall banking in just 6 years (S.B.P., 2008), and considering the DEA results we observe that they can endogenously sustain market penetration by being cost efficient. The profit efficiency ratios indicate superiority of $\mathrm{CB}$ followed by IB and IBD however the difference is not too significant. The window analysis approach of DEA sequentially ranked CB, IB and IBD respectively. The results also demonstrate that the SE is a major component for overall efficiency as PTE alone cannot take a bank to the efficient frontiers. The difference in the scores of IB and CB is insignificant. Being SE, the wide range of product portfolio helps CB in Pakistan to be cost efficient. Regulators should focus on pure banking form, conventional and Islamic, rather than inducing conventional ones to open Islamic subsidiaries or Islamic banking divisions because pure form banking provides an efficient banking as well as enables financial sector to be Shariah complaint. Further, we found inverse relationship of bank size with efficiency in all three types of banks which clearly suggests that mergers/acquisitions as well as increased capital base may not bring in banking efficiency, because increased assets require increased efficiency in asset management and utilization which seems to be a difficult task (Sufian, 2007). Furthermore, the correlations between financial ratios and DEA scores are significant, not particularly high, only in case of profit ratios. The conclusion to this is that the DEA and financial ratio measures offer different information and these methods could not be a substitute for each other.

We cannot determine allocative efficiency due to non-availability of costs data for banks' inputs. Moreover, currently the data of only one Islamic bank has sufficient coverage. Future studies may include increased number of Islamic banks.

\section{References}

Ahmed, T. (2008). Efficiency Analysis of Commercial Banks in Pakistan. Phd thesis, Department of Development Economics, University of Agriculture, Faisalabad, Pakistan. [Online] Available: http://eprints.hec.gov.pk/2492/1/2386.htm

Akmal, M., \& Saleem, M. (2008). Technical Efficiency of the Banking Sector in Pakistan. SBP Research Bulletin, 4(1), 61-80. [Online] Available: http://www.sbp.org.pk/research/bulletin/2008/vol4/Technical\%20Efficiency\%20of\%20the\%20Banking\%20Sect or\%20in\%20Pakistan.pdf

Al-Delaimi, K. S. K., \& Al-Ani, A. H. B. (2006). Using DEA to measure Cost Efficiency with an Application on Islamic Banks. Scientific Journal of Administrative Development, 4(IAD 2006), 134-156. [Online] Available: http://www.kantakji.com/fiqh/Files/Accountancy/811.pdf

Al-Shammari, M., \& Salimi, A. (1998). Modeling the operating efficiency of banks: a nonparametric methodology. Logistics Information Management, 11(1), 5-17. http://dx.doi.org/10.1108/09576059810202196

Avkiran, N. K. (1999). An application reference for data envelopment analysis in branch banking: helping the novice researcher. International Journal of Bank Marketing, 17(5), 206-220. http://dx.doi.org/10.1108/02652329910292675

Bdour, J. I., \& Al-khoury, A. F. (2008). Predicting change in bank efficiency in Jordan: a data envelopment analysis. Journal of Accounting \& Organizational Change 4(2), 162-181. http://dx.doi.org/10.1108/18325910810878955

Cooper, W. W., Seiford, L. M., \& Tone, K. (2007). Data Envelopment Analysis: A Comprehensive Text with Models, Applications and References. Policy, 46 (16), 1321-1332.

Danesh, I. A. (2007). An Investigation of Islamic Banks Performance: A Comparison with Conventional Banks. Masters Thesis, Cranfield University, UK.

Das, A., \& Ghosh, S. (2009). Financial Deregulation and Profit Efficiency: A Non-parametric Analysis of Indian Banks. Journal of Economics and Business, 61(6), 509-528. http://dx.doi.org/10.1016/j.jeconbus.2009.07.003

Drake, L., Hall, M. J. B., \& Simper, R. (2006). The impact of macroeconomic and regulatory factors on bank efficiency: A non-parametric analysis of Hong Kong's banking system. Journal of Banking \& Finance, 30(5), 1443-1466. http://dx.doi.org/10.1016/j.jbankfin.2005.03.022

Grigorian, D. A., \& Manole, V. (2005). A Cross-Country Non-Parametric Analysis of Bahrain's Banking Sector 
IMF Working Paper No. 05/117. [Online] Available: http://www.imf.org/external/pubs/ft/wp/2005/wp05117.pdf

Hassan, Z. (2005). Evaluation of Islamic banking performance: On the current use of econometric models. [Online] Available: http://mpra.ub.uni-muenchen.de/6461/

Iimi, A. (2004). Banking sector reforms in Pakistan: economies of scale and scope, and cost complementarities. Journal of Asian Economics, 15(3), 507-528. http://dx.doi.org/10.1016/j.asieco.2004.03.004

Isik, I., \& Hassan, M. K. (2002). Technical, scale and allocative efficiencies of Turkish banking industry. Journal of Banking \& Finance, 26(4), 719-766. http://dx.doi.org/10.1016/S0378-4266(01)00167-4

Johnes, J., Izzeldin, M., \& Pappas, V. (2009). The efficiency of Islamic and conventional banks in the Gulf Cooperation Council (GCC) countries: An analysis using financial ratios and data envelopment analysis. Lancaster University Management School, Working Papers Series, 2009(023). [Online] Available: http://eprints.lancs.ac.uk/48965/1/Document.pdf

Niazi, G. S. K. (2003). Measuring cost efficiency and productivity change of commercial banks in Pakistan 1991-2000. Phd thesis, Quaid-e Azam University, Islamabad, Pakistan. [Online] Available: http://prr.hec.gov.pk/thesis/2264.pdf

Omar, M. A., Rahman, A. R. A., Yusof, R. M., Majid, M. S. A., and Rasid, M. E. S. M. (2006). Efficiency of Commercial Banks in Malaysia. Asian Academy of Management Journal of Accounting and Finance, 2(2), 19-42. [Online] Available: http://web.usm.my/journal/aamjaf/vol\%202-2/2-2-2.pdf

Rizvi, S. F. A. (2001). Post-liberalisation Efficiency and Productivity of the Banking Sector in Pakistan. Pakistan Development Review, 40(4 (Part-II)), 605-632. [Online] Available: http://www.pide.org.pk/pdf/PDR/2001/Volume4/605-632.pdf

S.B.P. (2007). Islamic Banking Bulletin. http://www.sbp.org.pk/ibd/bulletin/2007/Feb-Bulletin.pdf

S.B.P. (2008). Islamic Banking Bulletin. [Online] Available: http://www.sbp.org.pk/ibd/bulletin/2008/Bulletin-Oct-Dec-2008.pdf

Seelanatha, S. (2007). Efficiency, productivity, change and market structure of the banking industry in Sri Lanka. PhD Thesis, University of Southern Queensland. [Online] Available: http://eprints.usq.edu.au/3589/2/Seelanatha_2007_whole.pdf

Sufian, F. (2007). Trends in the efficiency of Singapore's commercial banking groups: A non-stochastic frontier DEA window analysis approach. International Journal of Productivity and Performance Management, 56(2), 99-136. http://dx.doi.org/10.1108/17410400710722626

Tortosa-Ausina, E. (2004). An alternative conditioning scheme to explain efficiency differentials in banking. Economics Letters, 82(2), 147-155. http://dx.doi.org/10.1016/j.econlet.2003.08.009

Yeh, Q.-J. (1996). The Application of Data Envelopment Analysis in Conjunction with Financial Ratios for Bank Performance Evaluation. The Journal of the Operational Research Society, 47(8), 980-988. [Online] Available: http://www.jstor.org/stable/3010406

Yudistira, D. (2003). Efficiency in Islamic Banking: an Empirical Analysis of 18 Banks. Department of Economics, Loughborough University. [Online] Available: http://129.3.20.41/eps/fin/papers/0406/0406007.pdf 
Table 1. Financial Ratios for Bank Efficiency

\begin{tabular}{|l|l|}
\hline Ratio & \multicolumn{1}{|c|}{ Study } \\
\hline Return on Assets & $\begin{array}{l}\text { (Das \& Ghosh, 2009), (Johnes, et al., 2009), (Isik \& } \\
\text { Hassan, 2002) }\end{array}$ \\
\hline Return on Equity & $\begin{array}{l}\text { (Al-Shammari \& Salimi, 1998), (Isik \& Hassan, 2002), } \\
\text { (Danesh, 2007), (Das \& Ghosh, 2009) }\end{array}$ \\
\hline Non-interest expenses to assets. & (Johnes, et al., 2009) \\
\hline $\begin{array}{l}\text { Cash and portfolio investments } \\
\text { to deposits }\end{array}$ & (Al-Shammari \& Salimi, 1998), (Yeh, 1996) \\
\hline Net interest Margin & (Johnes, et al., 2009), (Yeh, 1996) \\
\hline Cost to income & (Johnes, et al., 2009) \\
\hline Other operating income to assets & (Yeh, 1996), (Johnes, et al., 2009) \\
\hline
\end{tabular}

Table 2. Input and Output Variables

\begin{tabular}{|l|l|}
\hline Input Variables & Output Variables \\
\hline Total Deposits ( Including short term funding) & Total Revenue ( interest and non interest) \\
\hline Total Expenses ( interest and non interest) & Earning Assets ( loans and other earning assets) \\
\hline
\end{tabular}

Table 3. CCR scores for conventional, dual and Islamic banks

\begin{tabular}{|l|r|r|r|r|r|r|r|r|}
\hline & 2003 & 2004 & 2005 & 2006 & 2007 & 2008 & Average & \multirow{2}{*}{ C-Average } \\
\hline & 1 & 1 & 0.9805 & & & & 0.9935 & \\
\hline & & 1 & 1 & 1 & & & 1 & \\
\hline & & & 1 & 1 & 0.9257 & & 0.9752 & \\
\hline IBD & 0.8511 & 0.7973 & 0.7191 & & & & 0.7892 & \\
\hline & & 0.7973 & 0.7373 & 0.7092 & & & 0.7479 & \\
\hline & & & 0.8743 & 0.7092 & 0.7905 & & 0.7914 & \\
\hline & & & & 0.7792 & 0.8374 & 0.7504 & 0.7890 & 0.7794 \\
\hline IB & 0.9293 & 0.9207 & 0.8346 & & & & 0.8947 & \\
\hline & & 0.9359 & 0.8545 & 0.8444 & & & 0.8783 & \\
\hline & & & 0.8725 & 0.8444 & 0.8358 & & 0.8509 & \\
\hline & & & & 1 & 0.9679 & 0.8967 & 0.9549 & 0.8947 \\
\hline Average & 0.9268 & 0.9084 & 0.8748 & 0.8762 & 0.8844 & 0.8529 & & \\
\hline
\end{tabular}


Table 4. BCC Scores for conventional, dual and Islamic bank

\begin{tabular}{|l|r|r|r|r|r|r|r|r|}
\hline & 2003 & 2004 & 2005 & 2006 & 2007 & 2008 & Average & C-Average \\
\hline CB & 1 & 1 & 1 & & & & 1 & \\
\hline & & 1 & 1 & 1 & & & 1 & \\
\hline & & & 1 & 1 & 1 & & 1 & 1 \\
\hline IBD & 1 & 1 & 1 & & & & 1 & \\
\hline & & 1 & 1 & 1 & & & 1 & \\
\hline & & & 1 & 0.9303 & 1 & & 0.9767 & \\
\hline & & & & 0.9586 & 1 & 1 & 0.9862 & 0.9907 \\
\hline IB & 1 & 0.9582 & 0.8423 & & & & 0.9335 & \\
\hline & & 1 & 0.9485 & 0.8636 & & & 0.9373 & \\
\hline & & & 1 & 0.9125 & 0.8560 & & 0.9228 & \\
\hline & & & & 1 & 0.9963 & 0.9733 & 0.9899 & 0.9459 \\
\hline Average & 1 & 0.9930 & 0.9767 & 0.9628 & 0.9754 & 0.9911 & & \\
\hline
\end{tabular}

Table 5. Scale efficiency scores for conventional, dual and Islamic bank

\begin{tabular}{|l|r|r|r|r|r|r|r|r|}
\hline & 2003 & 2004 & 2005 & 2006 & 2007 & 2008 & Average & C-Average \\
\hline CB & 1 & 1 & 0.9805 & & & & 0.9935 & \\
\hline & & 1 & 1 & 1 & & & 1 & \\
\hline & & & 1 & 1 & 0.9257 & & 0.9752 & \\
\hline & & & & 1 & 0.94884 & 0.9116 & 0.9534 & 0.9805 \\
\hline IBD & 0.8511 & 0.7973 & 0.7191 & & & & 0.7892 & \\
\hline & & 0.7973 & 0.7373 & 0.7092 & & & 0.7479 & \\
\hline & & & 0.8743 & 0.7623 & 0.7905 & & 0.8102 & \\
\hline & & & & 0.8128 & 0.8374 & 0.7504 & 0.8000 & 0.7866 \\
\hline IB & 0.9293 & 0.9603 & 0.9908 & & & & 0.9584 & \\
\hline & & 0.9359 & 0.9009 & 0.97776 & & & 0.9369 & \\
\hline & & & 0.8725 & 0.92530 & 0.9763 & & 0.9220 & \\
\hline & & & & 1 & 0.9714 & 0.9212 & 0.9646 & 0.9458 \\
\hline Average & 0.9268 & 0.9148 & 0.8956 & 0.91015 & 0.9066 & 0.8605 & & \\
\hline
\end{tabular}


Table 6. Correlations between Ratio and DEA efficiency scores

\begin{tabular}{|c|c|c|c|c|c|c|c|c|}
\hline & & OTE & CTI & NIE & NIM & OOI & ROA & ROE \\
\hline \multirow[t]{2}{*}{ OTE } & Pearson & 1 & -.164 & -.436 & $-.599(* *)$ & .209 & .289 & $.561\left(^{*}\right)$ \\
\hline & Spearman & 1.000 & -.110 & $-.472(*)$ & $-.506(*)$ & .095 & .135 & $.679(* *)$ \\
\hline \multirow[t]{2}{*}{ CTI } & Pearson & -.164 & 1 & .452 & .193 & $-.765(* *)$ & $-.899(* *)$ & -.463 \\
\hline & Spearman & -.110 & 1.000 & .465 & .170 & $-.822(* *)$ & $-.948(* *)$ & -.432 \\
\hline \multirow[t]{2}{*}{ NIE } & Pearson & -.436 & .452 & 1 & $.722(* *)$ & -.227 & -.459 & $-.517\left(^{*}\right)$ \\
\hline & Spearman & $-.472(*)$ & 465 & 1.000 & $.697(* *)$ & -.228 & -.447 & $-.707(* *)$ \\
\hline \multirow[t]{2}{*}{ NIM } & Pearson & $-.599(* *)$ & .193 & $.722(* *)$ & 1 & -.256 & -.262 & $-.588(*)$ \\
\hline & Spearman & $-.506\left(^{*}\right)$ & .170 & $.697(* *)$ & 1.000 & -.121 & -.170 & $-.709(* *)$ \\
\hline \multirow[t]{2}{*}{ OOI } & Pearson & .209 & $-.765(* *)$ & -.227 & -.256 & 1 & $.881(* *)$ & $.504(*)$ \\
\hline & Spearman & .095 & $-.822(* *)$ & -.228 & -.121 & 1.000 & $.841(* *)$ & .313 \\
\hline \multirow[t]{2}{*}{ ROA } & Pearson & .289 & $-.899(* *)$ & -.459 & -.262 & $.881(* *)$ & 1 & $.486\left(^{*}\right)$ \\
\hline & Spearman & .135 & $-.948(* *)$ & -.447 & -.170 & $.841(* *)$ & 1.000 & .459 \\
\hline \multirow[t]{2}{*}{ ROE } & Pearson & $.561(*)$ & -.463 & $-.517(*)$ & $-.588(*)$ & $.504(*)$ & $.486(*)$ & 1 \\
\hline & Spearman & $.679(* *)$ & -.432 & $-.707(* *)$ & $-.709(* *)$ & .313 & .459 & 1.000 \\
\hline
\end{tabular}

where OTE is overall technically efficiency; CTI is cost to income ratio; NIE is non-interest expenses to asset ratio; NIM is net interest margin ratio; $\mathrm{OOI}$ is other operating income ratio; ROA is return on assets ratio; and ROE is return on equity ratio.

** Correlation is significant at the 0.01 level (2-tailed).

* Correlation is significant at the 0.05 level (2-tailed).
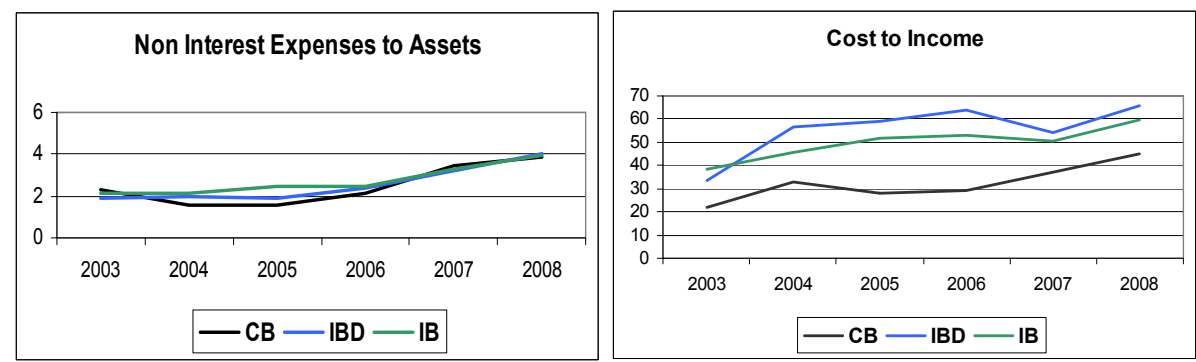

Figure 1. Ratio Analysis: Cost Efficiency
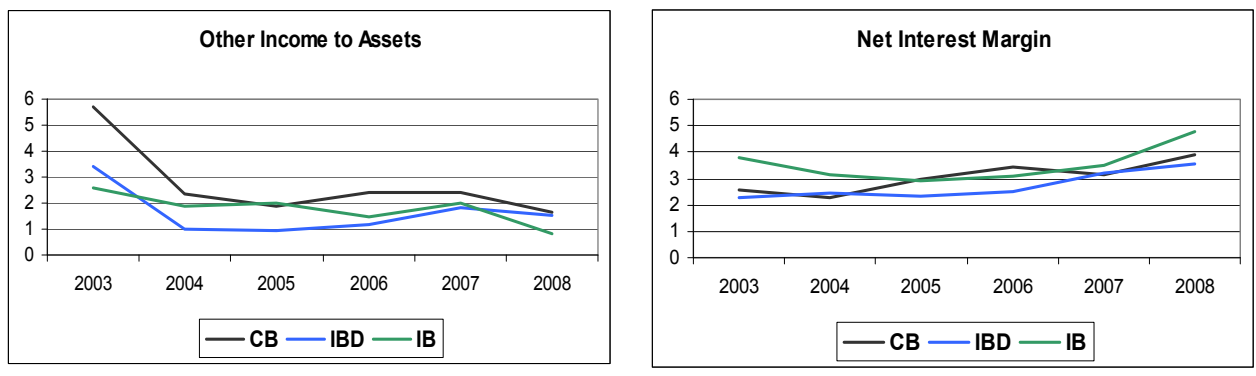

Figure 2. Ratio Analysis: Income Efficiency 

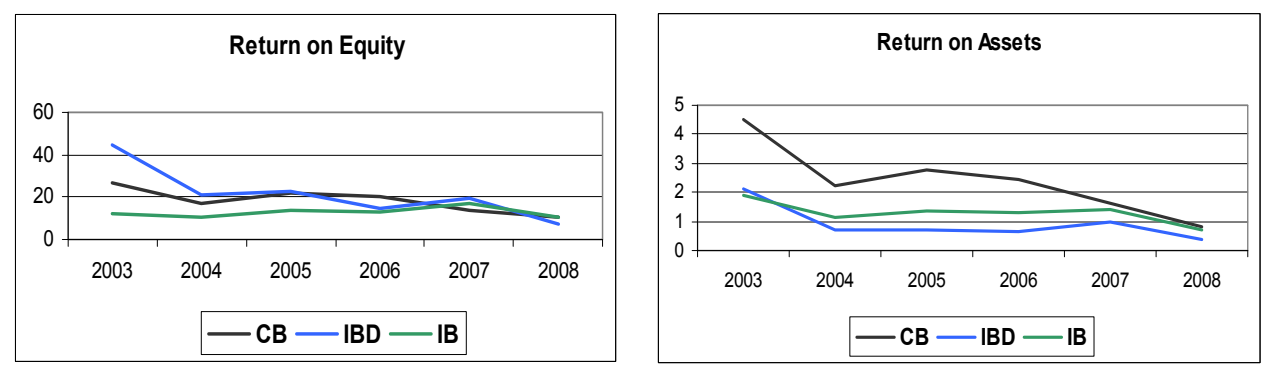

Figure 3. Ratio Analysis: Return Efficiency
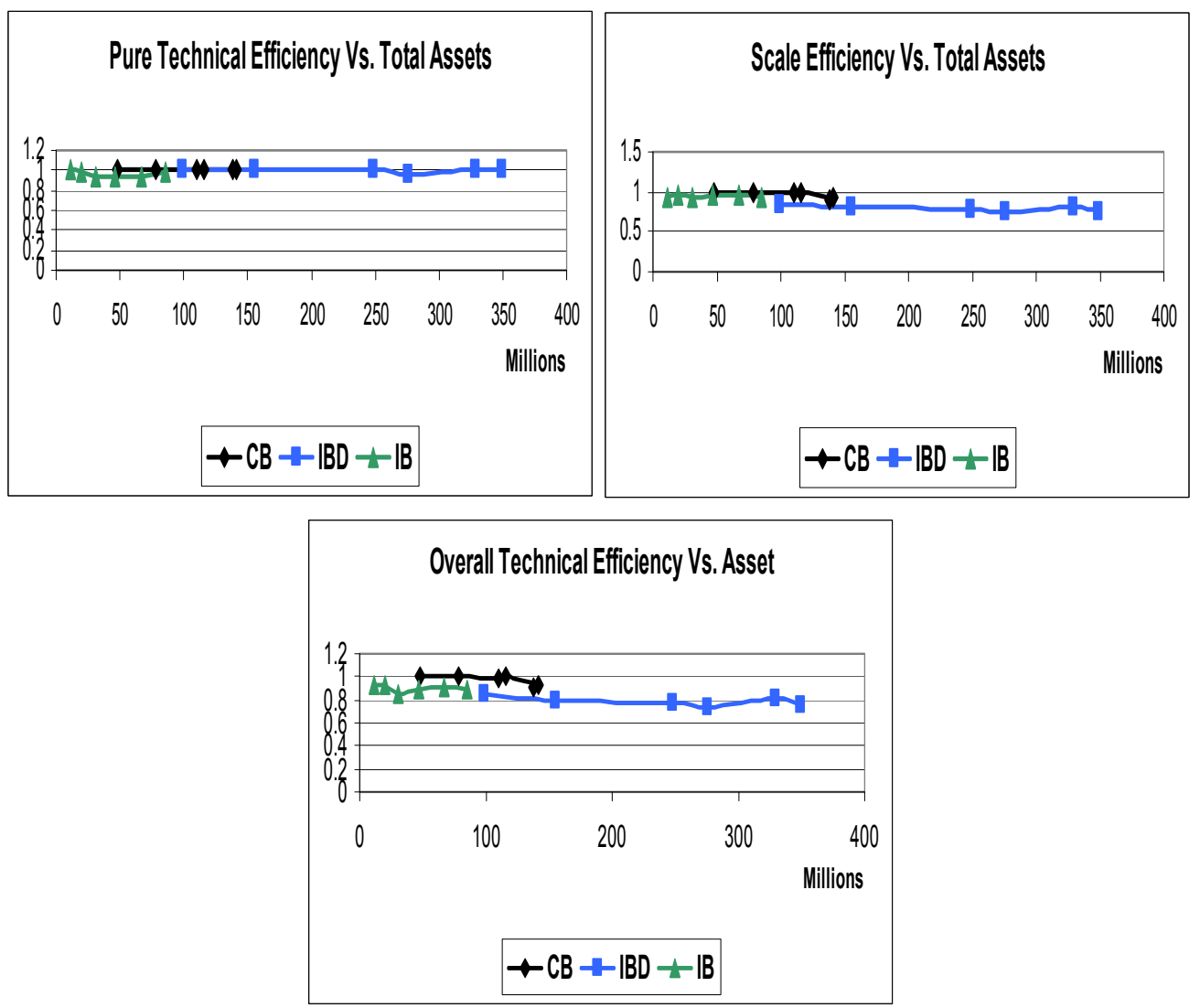

Figure 4. Efficiency scores vs. Assets of banks 